\title{
Mobile Banking: A Strategic Approach to Promote Financial Inclusion for Women Entrepreneurs?
}

\author{
Ragui, M. \\ Business Administration Department, School of Business, Kenyatta University, Nairobi, Kenya
}

\begin{abstract}
Financial inclusion denotes provision of inexpensive financial services like savings, loans, access to payments and remittance facilities, and insurance services by the already recognized system to those who are likely to be excluded. Compared to the UK's 6\% and Ghana's 12\%, Kenya's financial exclusion of $23 \%$ is far adrift and a springboard towards establishing barriers to acceptable inclusion standards. This gap informed this study, which was intended to examine the strategic approaches adopted by the Kenyan commercial banks in promoting financial inclusion of women entrepreneurs. This paper however concentrates on mobile banking as one of the strategic approach used by the banks. Towards meeting this objective, the study adopted a descriptive survey research design, taking the heads of the relevant target strategic units in the 11 NSE listed commercial banks as the study population. The study used primary data obtained from the banks through administration of semi-structured questionnaire. Obtained data were analyzed using descriptive and inferential statistical techniques. The study found that the strategic approaches banks adopted giving way to application of alternative banking channels to women entrepreneurs had significant effects on financial inclusion, where previously unbanked women entrepreneurs got a chance to own formal accounts. The findings indicate that under mobile banking there were significant products which were strategically designed to attract women entrepreneurs. However, banks were still cautious in offering customers products which would compromise the institutions' return capability. This informed the rationale behind small mobile-credit volumes offered on partnership between the banking institution and phone service providers. On the basis of the study's findings, the study recommended that commercial banks should enter into long-lasting and beneficial strategic partnerships with a wide range of service providers towards ensuring that women entrepreneurs have equally wider service alternatives. In addition, it is recommended that banking institutions should seek further innovations in enhancing their system infrastructures and adoption of cheaper internet alternatives.
\end{abstract}

Keywords: Commercial Banks, Financial Inclusion, M-Banking, SMEs, Women Entrepreneurs.

\section{Introduction}

Financial services are of immense importance in any economy and specifically for the small and medium enterprises entrepreneurs. According to Beck, Cull, Fuchs, Getenga, Gatere, Randa and Trandafir (2010), financial institutions play an important role in the resource allocation process. SMEs entrepreneurs need finances as a resource to grow their businesses. While linking entrepreneurs to the theory of economics, Wiklund and Shepherd (2005) indicated their willingness to rejuvenate market offerings, innovate, risks taking, trying out of new and uncertain products, services, markets and being more proactive than competitors towards exploring new business opportunities. All these calls for resources and therefore finances is a critical resource for their mission to be accomplished. Women entrepreneurs participate largely in socio-economic development and are about $43 \%$ of business owners in Kenya (World Bank, 2015). Women participate in a wide range of entrepreneurial activities and their activities in the have paid off in form of many newly-established enterprises for job and wealth creation (Global Entrepreneurship Monitor (GEM) 2005).

Efficiency of capital accumulation and economic growth can only be achieved through investments which are enabled by liquidity of SMEs entrepreneurs. Liquidity is the primary role of the banking sector therefore very critical for any economy (Diamond \& Dybvig, 2003). Economy grows significantly when the economically disadvantages women entrepreneurs are able to access financial services leading to distribution of opportunities more evenly. Inclusion of all in access of financial services therefore becomes a priority for the major players in the financial system (Diamond \& Dybvig, 2003). Chibba (2009) advocates for financial inclusion as the intervention strategy and deliberate effort to overcome accessibility challenges to formal financial services.

Chibba (2009) defines financial inclusion as a strategy that seeks to reduce market friction that hinders the markets from operating to benefit the poor and underprivileged. The intervention offers incremental and complementary solutions to tackle poverty and promote inclusive development. It purposes to have the unbanked population included in the formal financial system to enable them access financial services ranging from savings, payments, and transfers to credit and insurance. Beck et al. (2010) looks at financial inclusion or banking sector outreach as the process of making an array of required financial services available to all, at a fair 
price, at the right place, form and time. Financial inclusion aims at advantaging the poor majority of who do not use formal financial services and in this case the SMEs entrepreneurs. Sarma and Pais (2010), proponents of financial inclusion, opine that financial exclusion leads to loss of opportunity to grow, a retarded country's growth, and increased poverty levels.

United Nations (2007) asserts that over 2.7 billion entrepreneurs around the world have no access to formal financial services like savings accounts, credit, insurance, and payment services. Although a universal problem, the financially excluded person is more often than not the average citizen (Chibba, 2009). Chaia, Aparna, Tony, Maria, Jonathan and Robert (2010) confirm that more than 80 percent of the adult population, 325 million people, remain financially excluded. In addition, those with access are limited to having a bank account and not accessing other financial services products. According to Sarma and Pias (2011), financial exclusion often reinforces other aspects of social exclusion. It is therefore critical to include all women entrepreneurs for socio-economic development.

Jacob (2005) categorises financial product consumers generally into four main groups which determine the strategic approaches to be adopted in financial inclusion. First, there are those women entrepreneurs who prefer human interaction; second, those who are open to new financial inclusion channels; third, those who are unsure and therefore undecided; and fourth, those who have differing preferences, depending on the individual services in question. Specifically, the second group is made up of younger, wealthier and highly educated clients, who have less time to visit a branch and who feel at home with the new technologies used in the alternative channels. The anywhere, anytime availability, and accessibility of inclusion channels coupled with the time saving and lower costs involved, make life easier for them and therefore increases their customer loyalty (Jacob, 2005). It is important that the bank addresses each group of customers with the financial inclusion options they require. The technology employed should also be perceived as reliable and simple to use (Claessens, 2006).

Kenya has achieved significant milestones towards financial inclusion on women entrepreneurs. Between the years 2006 and 2009, for instance, the formally included went up from $18.9 \%$ to $22.6 \%$ while the proportion of financially excluded decreased from $38.4 \%$ to $32.7 \%$. Most notable is savings rates which increased in the lowest wealth quintile, from $23 \%$ in 2006 to $29 \%$ in 2009. In addition, bank usage increased in every single wealth quintile between 2006 and 2009. The number of bank branches in the country also grew by $12 \%$. Introduction of mobile money and the responding rollout of branchless agency banking models by commercial banks have also assisted in gains of the banks (Arnold, Beck \& Ellis, 2011). Over the last five years, financial service providers have moved deeper into the low-income market leading to cut throat competition amongst them for the market. Moreover, the Kenyan government has introduced appropriate regulations to facilitate low-income banking and strengthen SACCOs and MFIs. Notably, the vital role of the financial system and technology is entrenched in the Kenya's development blue print, Vision 2030, which aims at transforming the country into a newly industrialized middle-income country that provides high quality of life to its citizenry by the year 2030 (Njunji, 2009).

As envisaged in Kenya's Vision 2030, Kenya strives to become a regional financial hub. It is expected to be vibrant, efficient and globally competitive, a financial system which should drive savings and investments. The ultimate goal is a high broad-based and sustainable economic growth (Financial Sector Deepening, 2011). Contrary to this, however, the country seems to be performing poorly in strategic enhancement of financial inclusion especially for bottom of pyramid populace. According to CBK (2014), by end of 2013, a proportion of $23 \%$ of adult Kenyans, estimated at 5.9 million and mainly from the low economic category, had no access to formal financial services offered by the commercial banks. Comparatively, the country's un-banked proportion is now far above the $6 \%$ observed in the United Kingdom and 12\% in Ghana (FinAccess, 2009). In spite of the remarkable achievements in the commercial bank intermediation towards attainment of Kenya's development agenda (CBK, 2014), this study presumed existence of service provision gaps which needed to be addressed in order to include majority of Kenyans in the financial system, and hence participation in economic activities.

From the aforementioned, financial inclusion arguably stands out as a core recipe to correcting the social mess which excludes part of the populace from economic participation. The fact that close to quarter of the Kenyans were excluded from the country's formal financial activities, with women contributing to almost $87 \%$ of them $(\mathrm{CBK}, 2014)$, formed the basis for this study in order to examine the effectiveness of the commercial banks' strategic approaches in promoting inclusion of women entrepreneurs. This was realized under the presumption that strategic approaches, especially those involving technology-based banking alternatives, have a strong bearing on financial inclusion in the economy.

The scope of this study was defined by the four relevant measures of financial inclusion strategies in use by the banks today on women entrepreneurs which included agency supervision, ATM sections, internet banking sections, and mobile banking units (M-banking). This paper is restricted to the M-banking strategy. 


\section{Theoretical Review}

The study was anchored on two theories: agency theory and the finance-growth theory. Agency theory postulates that the firm consists of a contract between the owners of economic resources (the principals) and managers (the agents) who are charged with using and controlling those resources (Lambert, 2002). The registered commercial banks are regarded as the principals while the alternative channels they adopt perform the agency duties. Through this relationship, the study presumes that financial inclusion is dependent on the extent of agency linkages that the banks establish.

The theory of finance-growth advocates that financial inclusion bring about a productive environment for growth through 'supply leading' or 'demand-following' effect. The theory also identifies lack of access to finance to women entrepreneurs as an acute factor responsible for persistent income inequality as well as slower growth of economy (Coleman, 2000). Access to safe, easy and affordable finance is identified as a pre-condition for accelerating growth and reducing income disparities and poverty which creates equal opportunities, enables economically and socially excluded women entrepreneurs to assimilate better into the economy and actively contribute to development and protect themselves against economic shocks (Serrao et al., 2012). Ndebbio (2004) posits that banks support the economy growth through well-organized markets for funds. The main argument of the theory is that financial inclusion evolves as the demands for financial services increases from an already budding economy. In the study, it is presumed that commercial banks seek to broaden financial inclusion due to the drive to create a favourable environment for women entrepreneurs' productivity.

\section{Research Methodology}

Descriptive Survey design was used in the study. De Vaus (2002) argues that good description is the basis of sound theory and that unless something is described accurately and thoroughly, it cannot be explained. Descriptive surveys are often undertaken to ascertain attitudes, values and opinions. As Black (2003) notes, however, there may be differences between the opinions found through a survey, which is a description of people's perceptions, and the actual reality of practice. That is, people may articulate a particular view, but in practice behave differently. Caution was hence exercised when drawing conclusions from the survey.

The study targeted all NSE listed commercial banks which were also licensed and regulated pursuant to the provisions of the Banking Act and the regulations and prudential guidelines issued by the Central Bank of Kenya. By time of study, there were 11 institutions meeting the study inclusion criteria.

A census approach was used and 4 officers were randomly selected from each institution making it 44 officers working in strategic positions of the NSE listed commercial banks as they had better understanding of the banking procedures. It was also assumed they knew the needs of women entrepreneurs and therefore they were in a better position to respond to the research questions. According to Dillman (2005) conducting a census often results in enough respondents to have a high degree of statistical confidence in the survey results. Moreover, the census gives every essential participant a chance to alter the direction of survey findings, thus giving the study a higher reliability possibility.

A semi-structured questionnaire was designed to collect data from the respondents. The questionnaire accommodated all the essential objectively verifiable indicators under each predictor variable. According to Dillman (2005), within business and management research, the greatest use of questionnaires is made to accomplish a wide range of feedbacks because each respondent is asked to respond to the same set of questions and it provides an efficient way of collecting responses from a large sample prior to quantitative analysis.

The questionnaire section used for this paper sought information on the effect of M-banking strategy on financial inclusion of women entrepreneurs. This was determined by studying indicators that included Mbanking product range, proportion of M-banking transactions, service coverage in Kenya, provision of credit and related facilities, and strategic partnerships with mobile service providers.

The refined and organized quantitative data were analyzed using descriptive and relational statistics. Moreover, inferential statistics were used to test the statistical significance of effects imparted by the study's predictor variables. Specifically, the test-statistics used were t-test and F-test. According to Hair et al. (2002), inferential approach is essential when finding a way of condensing the information contained in a number of original variables into a smaller set of factors. The statistics were generated with aid of the computer software, Statistical Package for Social Sciences (SPSS) Version 20.0. The study's non-metric, open-ended responses were analyzed using content analysis procedure, whereby the pool of diverse responses was reduced to a handful of key issues in a reliable manner.

\section{Research Findings}

All the 44 respondents required to complete the administered questionnaire fully cooperated in the study thus leading to a response rate of $100 \%$. Such a high return rate was construed as a fundamental element in bolstering the findings' reliability and generalization. The effect of mobile banking on financial inclusion on women entrepreneurs was determined by studying indicators which included M-banking product range, 
proportion of M-banking transactions, service coverage in Kenya, provision of credit and related facilities, and strategic partnerships with mobile service providers.

\subsection{M-Banking Products Range}

From the findings on the M-Banking products range, the M-banking channel was highly preferred for making money transfers $(27.3 \%)$ and settlement of bills $(27.3 \%)$. Women entrepreneurs were also enabled to open virtue accounts (18\%) through which they performed marked transactions while another set used Mbanking for making deposits and withdrawals (18\%). The smallest of the M-banking usage was for M-credit functionality which enabled women entrepreneurs to borrow loans and repay through their mobile phones. The fact that there was clientele in at least every product on offer was an adequate indicator that M-banking was instrumental in promoting women entrepreneurs' financial inclusion. It also revealed that women entrepreneurs needs differs and therefore banking inclusion could be for different reasons. This enlightens the banks to carry out an in-depth survey on the women entrepreneurs needs to ensure they increase their product ranges to cover all these needs.

The findings concur with Tubin (2010) who acknowledges that the banking industry has been experiencing significant changes in the recent past. As the mobile revolution ushers in a new way of thinking, traditional banks are stepping up to offer a range of mobile banking products. This allows banks to service their customers better, as well as to reduce operational costs and provide the convenience of anywhere, anytime banking. This increases value to the women entrepreneurs giving them more reasons for formal banking.

\subsection{Transaction Volumes}

The study sought to establish the transaction volume from women entrepreneurs by the selected banks in measuring the contributory value of M-banking in the day-to-day institutional operations. Table 1 presents the findings.

Table 1: Transaction Proportions

\begin{tabular}{|l|c|c|c|c|c|}
\hline Measure & N & Minimum & Maximum & Mean & Std. Deviation \\
\hline $\begin{array}{l}\text { Proportion of M- } \\
\text { Banking Services (\%) }\end{array}$ & 11 & 9 & 18 & 13.18 & 2.639 \\
\hline Valid N & 11 & & & & \\
\hline
\end{tabular}

Source: Field Data (2016)

Table 1 shows the minimum and maximum M-banking transactional proportions in the year 2015 as $9 \%$ and $18 \%$ respectively, leading to a group aggregated mean of $13.18 \%$ with a standard deviation of 2.6. This was regarded a very significant proportion implying a positive uptake of M-banking products, hence a boost in financial inclusion. The transactions volumes are moderately high and according to the respondents on a qualitative question, the women entrepreneurs seems to be making more transactions on M-banking than on the conventional bank visits. This imply that uptake of M-banking could increase women entrepreneurs' financial inclusion.

\subsection{Geographical Coverage}

The extent to which M-banking services were accessible was investigated and found to be a hindrance to women entrepreneurs' financial inclusion maximization. Asked if there were some areas in Kenya that their banks' M-banking package did not cover, it was found that at least $90 \%$ of the commercial banks listed at the NSE were unable to design M-banking services to reach all women entrepreneurs in Kenya. This was linked to poor telephony service coverage which had not captured all the urban and rural areas in the country. There was a paltry of $9 \%$ with such ability which meant investing in more than one phone service providers and other alternative options. This is similar to Sarma and Pais (2010) who acknowledge inherent challenges in Mbanking are associated with unreliable and underdeveloped infrastructures, thus making its services limited to a portion of the populace. Women entrepreneurs in areas with poor coverage are therefore difficult to include in the formal banking if they want to rely on M-banking. Conventional banking in such condition supersedes $\mathrm{M}$ banking. On a qualitative question, the respondents indicated that some women like keeping their financing transactions a secret and therefore would not like to be going to a physical bank. Distances also could hinder some women where M-banking is not available. This calls for the banks to collaborate with mobile telephone providers to increase their broadband to cover as many areas as possible.

\subsection{Credit Facilities on M-banking}

Further, the study focused on M-Banking credit facility as the service sweeteners that banks embraced in encouraging M-banking usability. The study found that M-credit was only accessible to $27 \%$ of the women entrepreneurs, leaving the other $73 \%$ operating without the 'sweetener' M-banking product. While the banks' 
failure to sweeten their M-banking platform by coating it with mobile-credit was a cautious investment strategy, elaborate strategic partnerships with mobile service providers were of essence and this caused the entry delay by majority of banks. This is because the mobile service providers (Safaricom Kenya Ltd and Airtel Kenya Ltd) have also ventured into money transfer using mobile phones. They therefore form a new competitor to the banks and therefore M-banking might fail as a strategy of financial inclusion if not rethought.

\subsection{Strategic Partnerships}

The existence of strategic partnerships was studies to measure the extent of a collective effort by both banking institutions and phone service providers towards enhancement of women entrepreneurs' financial inclusion through the M-banking alternative. The findings illustrates that majority of the banks $(64 \%)$ had entered into strategic partnerships with mobile phone service providers that would be essential in concretizing M-banking as an alternative channel and in turn bolstering advocacy for financial inclusion. The remaining $36 \%$ were yet to enroll in any partnership other than the normal interfaces. Many women entrepreneurs might not be owning or even knowing how to operate a computer or a laptop. A mobile phone is therefore the simplest device to use in transactions. Failure to enter into strategic partnerships will leave a vacuum which the mobile phone providers are taking up to provide money transfer services.

\subsection{Extent of Financial Inclusion}

The study further examined the pattern of financial inclusion over a period of five years to establish inherent variations. Table 2 presents the findings.

Table 2: Financial Inclusion Trend between 2011 and 2014

\begin{tabular}{cc}
\hline Year under Review & Mean \\
\hline 2011 & 16.500 \\
2012 & 18.100 \\
2013 & 19.800 \\
2014 & 20.300 \\
2015 & 21.300 \\
Valid N & 5 \\
\hline
\end{tabular}

Source: Field Data(2016)

Table 2 shows that between the years 2011 and 2015, the number of the formally banked in Kenya grew steadily by a significant margin of $29 \%$. This growth was closely associated with the banking institutions' strategic approaches towards alternative service channels that help attract the previously unbanked women entrepreneurs, thus making an additive contribution to financial inclusion in Kenya.

\section{Regression Modelling}

The study adopted Ordinary Least Squares (OLS) regression approach to determine quantitative impact of the strategic banking alternatives on women entrepreneurs' financial inclusion. In the model, the respective numbers of women entrepreneurs in ATM banking, mobile banking, agency banking, and internet banking strategic banking channels were set as predictor variables simultaneously, while the average banking transactions per day were set to be the criterion variable. The model was structured as generally expressed in equation 1.

$Y=a+\beta_{1} x_{1}+\beta_{2} x_{2}+\beta_{3} x_{3}+\beta_{4} x_{4}+\mu$. Equation 1

In the model, $Y$ represents the indicator for women entrepreneurs' financial inclusion; $x_{1}, x_{4}, x_{3}, x_{2}$ denote internet, agency, mobile and ATM stategies respectively; $\beta_{1}, \beta_{2}, \beta_{3}$ and $\beta_{4}$ are constants; and $\mu$ is the stochastic error term.

Inclusion of the four predictor variables in the model explained $96.2 \%$ of the total variation in the dependent variable, women entrepreneurs' financial inclusion (average daily transactions). This implied that the four alternative banking strategy channels were the predominantly preferred means of transactions in the entire banking industry. Further, it confirmed a customer-preference shift from physical-branch services to more flexible and dependable modes of customer satisfaction. In Tables 3, the regression model summary is given.

Table 3: Regression Model Summary

\begin{tabular}{ccccc}
\hline Model & R & R Square & Adjusted R Square & Std. Error of the Estimate \\
\hline 1 & $.989^{\mathrm{a}}$ & .977 & .962 & 351.790 \\
\hline
\end{tabular}

a. Predictors: (Constant), ATM, Agency Banking, Number of Internet Banking, M-Banking

Source: Field Data (2016) 
Table 4 reports on ANOVA which was used to assess the model's overall significance based on F-test and t-test. Given that $F>2.0$ and $p<0.05$, the model was found to be statistically significant.

Table 4: ANOVA

\begin{tabular}{lccccc}
\hline Model & Sum of Squares & Df & Mean Square & F & Sig. \\
\hline Regression & 31973209.431 & 4 & 7993302.358 & 64.589 & $.000^{\mathrm{b}}$ \\
Residual & 742535.114 & 6 & 123755.852 & \\
Total & 32715744.545 & 10 & & \\
\hline
\end{tabular}

a. Dependent Variable: Women Entrepreneur's Financial Inclusion

b. Predictors: (Constant), ATM, Agency Banking, Internet Banking, M-Banking

Source: Field Data (2016)

In Table 5, the standardized beta coefficients give a measure of the contribution of each variable to the model. A large value indicates that a unit change in the predictor variable has a large effect on the criterion variable. The $\mathrm{t}$ and $\mathrm{Sig}(\mathrm{p})$ values give a rough indication of the impact of each predictor variable; a bigger absolute $t$ value and smaller $p$ value suggests that a predictor variable is having a large impact on the criterion variable.

Table 5: Regression Coefficients

\begin{tabular}{lccccc}
\hline Model & \multicolumn{2}{c}{ Unstandardized Coefficients } & $\begin{array}{c}\text { Standardized } \\
\text { Coefficients }\end{array}$ & t & Sig. \\
\cline { 2 - 4 } & $\mathbf{B}$ & Std. Error & Beta & \\
\hline (Constant) & 5581.838 & 1052.985 & & 5.301 & .002 \\
Internet Banking & .002 & .003 & .025 & 3.114 & .003 \\
Banking & .003 & .000 & .206 & 12.36 & .000 \\
M-Banking & .005 & .003 & .381 & 2.619 & .007 \\
ATM & .007 & .001 & .618 & 6.374 & .001 \\
\hline
\end{tabular}

a. Dependent Variable: Women Entrepreneurs' Financial Inclusion

Source: Field Data (2016)

Table 5 indicates that all the four predictor variables were statistically significant in influencing financial inclusion $(\mathrm{F}>2.000$ and $\mathrm{t}<0.05)$. The specific regression model resulting from the analysis is as follows:

$\mathbf{Y}=\mathbf{5 5 8 2}+\mathbf{0 . 0 0 2} x_{1}+\mathbf{0 . 0 0 3} x_{2}+\mathbf{0 . 0 0 5} x_{3}+\mathbf{0 . 0 0 7} x_{4}+\mu$

The model shows that banking automation through ATMs was the leading strategic innovation to women entrepreneurs financial inclusion. This was associated to the ATMs' relatively longer existence over the other strategic banking options. In effect, for every ATM additional membership, there was an upward variation in transactions by $0.7 \%$. In addition, a single mobile-banking listing by the industry players boosted daily transactions by $0.5 \%$. The fact that not all banking institutions had embraced agency banking saw the alternative channel's contributory value subsidize to $0.3 \%$ per unit effect. Notably, however, the least effect was from internet banking where an addition online account elevated average daily transactions by $0.2 \%$. The fact that all model-coefficients were non-negative explicitly implied that automated, mobile, agency and internet banking options were all competitive options geared towards promoting women entrepreneurs financial inclusion.

\section{Conclusions}

Regarding the mobile banking, there were significant products strategically designed to attract women entrepreneurs for financial inclusion. It was also found that women were not ready to be exposed and therefore considers M-banking as a more safer way of banking as compared to traditional physical banking. The geographical coverage is not $100 \%$ making it difficult to use M-banking as the inclusion strategy exclusively. All the products in M-banking were in use by the women entrepreneurs showing they are in need of the products. Women entrepreneurs did however not embrace M-credit facility and on the other hand, banks are still cautious in offering the product as it could compromise the institutions' return capability as no collateral is required on m-credit loans. Strategic partnerships with phone service provider is also to be fully welcome by the banks.

\section{Recommendations}

The study recommends that the government strengthen the policy against non-payment of loans which should include $\mathrm{m}$-credit where physical papers do not exist but virtual borrowing. This will enable to bank gain confidence on m-credit as it retains its profitability. It will also enable women entrepreneurs use a facility that is well guided by the law. 
The banks need to re-look into the needs of women entrepreneurs to re-design or improve the Mbanking products range. This will help in increasing financial inclusion as many joins formal banking for different packages. It will also help them in achieving their objective of secrecy banking as confidentiality will be assured by the products.

The banks could enter into beneficial strategic partnerships with a wide range of service providers towards ensuring that wider geographical range is covered. This will enhance M-banking services in the banking industry while increasing women entrepreneurs financial inclusion and profitability of the banks.

\section{References}

[1]. Arnold, S., Beck, T. \& Ellis, K. (2011), Financial Inclusion in Kenya: Survey Results and Analysis from FinAccess 2009

[2]. Beck, T., Cull, R., Fuchs, M., Getenga, J., Gatere, P., Randa, J. \& Trandafir, M. (2010), Banking Sector Stability, Efficiency, and Outreach in Kenya', Washington DC: World Bank Policy Research Working Paper 5442.

[3]. CBK Annual Report (2014), Nairobi.

[4]. Central Bank of Kenya, (2014). Guidelines on Agent Banking, Banking Journal: CBK/15, pp 27-37.

[5]. Chaia, A., Aparna D., Tony G., Maria G., Jonathan M. \& Robert S. (2010), Half the World is Unbanked. World Bank Policy Research Working Paper 5028

[6]. Chibba, M. (2009), Financial Inclusion, Poverty Reduction and the Millennium Development Goals, European Journal of Development Research, 213-230.

[7]. Claessens, S. (2006), Access to Financial Services: A Review of the Issues and Public Policy Objectives, The World Bank Research Observer 21(2): 207-240.

[8]. Coleman, S. (2000). Access to capital and terms of credit: A comparison of men- and women owned small businesses. Journal of Small Business Management, Vol 38 pp 37-52

[9]. Diamond, D.W. \& Dybvig, P. (2003), Bank Runs, deposit insurance and liquidity, Journal of Political Economy, 91, 401-419

[10]. Dilliman, D.A. (2005), Mail and internet surveys: The total design method ( ${ }^{\text {rd }}$ ed.), New York: John Wiley.

[11]. Diniz G., Pozzen, D. \& Jayo, M. (2008), Liquidity Risk, Liquidity Creation and Financial Fragility: A Theory of Banking, Journal of Political Economy 109(2): 287-327.

[12]. FinAccess, 2009. National Survey Results. Dynamics of Kenya's changing landscape. Central Bank of Kenya and Financial Sector Deepening publication

[13]. Finance Sector Deepening (2011), Results of the FinAccess National Survey: Dynamics of Kenya's Changing Financial Landscape, Nairobi: FinAccess and Financial Sector Deepening Kenya.

[14]. Gatewood, E,G., Carter, N.M., Brush,C.G, Green, P.G., and Hart, M.M.(2004). Women entrepreneurs, Their Ventures and the Venture Capital Industry: Annotated Bibliography. Stockholm ESBRI.

[15]. GEM, (2005). "Report on Women and Entrepreneurship", Global Entrepreneurship Monitor, June.

[16]. Hair, J., Anderson R., Tatham, R. \& Black W. (2002), Multivariate Data Analysis, Fifth Edition, Prentice Hall.

[17]. Jacob L. (2005) Financial Inclusion in the UK: Review of Policy and Practice, Bristol: Joseph Rowntree Foundation.

[18]. Lambert, M. (2002), Financial Inclusion: Challenges \& Opportunities, 23rd Skoch Summit 2010

[19]. Ndebbio J, (2004), Financial deepening, economic growth and development: Evidence from selected sub- Saharan African countries, African Economic Research Consortium (AERC) Research Paper 142, Nairobi, Kenya.

[20]. Njenga, A. K (2010), Mobile phone banking: Usage experience in Kenya, International Journal of Management, 12(3): 134-142.

[21]. Porteous, D. (2006), The Enabling Environment for Mobile Banking in Africa, London: DFID.

[22]. Sarker S \& Wells J D, (2003), Understanding mobile handheld device use and adoption. Communication of the ACM V $46 \mathrm{n} 12$

[23]. Sarma, M. \& Pais, J. (2010). Financial Inclusion and Development. Journal of international development, 68, 75-69.

[24]. Serrao M, A.H. Sequeira \& B.V. Hans (2012). Designing a Methodology to Investigate Accessibility and Impact of Financial Inclusion (March 18, 2012).

[25]. Tubin, G. (2010), Lessons Learned: Eight US Financial Institutions Reveal Mobile Banking Benefits. TowerGroup. Retrieved September 1, 2014, from http://www.clairmail.com/towerstudy

[26]. United Nations (2007), Press Conference on Best Practice for Financial Inclusion, UN department of public information, 14th September.

[27]. Wiklund, J and Shepherd, D. A. (2005). Entrepreneurial Small Business: A Resource-Based Perspective. Chelternham, UK: Edward Elger Publishing

Ragui M. "Mobile Banking: A Strategic Approach to Promote Financial Inclusion for Women Entrepreneurs?." IOSR Journal of Business and Management (IOSR-JBM) 19.7 (2017): 48-54. 